\title{
PERNIKAHAN WANITA HAMIL KARENA ZINA (MARRIED BY ACCIDENT) DALAM PERSPEKTIF SOSIO KULTURAL MASYARAKAT METRO UTARA (Studi Tentang Dampak dan Upaya Penanggulangannya)
}

\author{
Oleh: Fatkul Mujib, M.H \\ (Hakim di Pengadilan Agama Kab. Bangka Barat)
}

\begin{abstract}
Marriage of pregnant women because of adultery is a legal matter as well as a social problem. Based on research on the reality of marriage of pregnant women due to adultery that occurs in Metro North District, the following matters can be concluded:

Metro North people's perceptions of the legal provisions related to the marriage of pregnant women because adultery is largely influenced by the function of social institutions through religious leaders and community leaders, this has implications for the effectiveness and understanding of the public regarding formal law regarding the issue of pregnant marriage.

Marriage of pregnant women due to adultery that occurs in Metro Utara Subdistrict as a social reality which is considered normal then constructs the sociological paradigm of the community of Metro Utara Subdistrict, which empirically describes the people's passivity towards the case of pregnant women due to adultery.

Countermeasures for the issue of marriage of pregnant women due to adultery have been carried out by various parties in Metro Utara. These efforts include preventive, curative and repressive efforts. However, the existing efforts are still pragmatic and incidental.
\end{abstract}

\section{PENDAHULUAN}

Berbagai faktor yang melatarbelakangi terjadinya pernikahan wanita hamil karena zina di Metro Utara yang merefleksikan problem sosial di dalamnya. Masalah pendidikan, kualitas keluarga dan lingkungan serta pemahaman tradisi yang tereduksi dengan perkembangan masyarakat merupakan hal yang perlu diperhatikan terkait peristiwa pernikahan wanita hamil karena zina yang ada. Hal ini sebagaimana direpresentasikan di Kelurahan Karangrejo yang terdiri dari 11 rukun warga (RW), yang pada tiap RW tersebut ditemukan pernikahan wanita hamil karena zina dengan rata-rata tujuh kasus dengan berbagai latar belakang. ${ }^{1}$

Persoalan tersebut tidak hanya menyoal jumlah kasus pernikahan hamil karena zina yang terjadi, namun pada aspek sosiologis hal ini menjadi persoalan terkait pembangunan hukum pada masyarakat dengan realitas

${ }^{1}$ Data diperoleh melalui diskusi dan interview pada Focus Group Discussion (FGD) kelompok peserta PKH (Program Keluarga Harapan) Kec. Metro Utara , November 2015. 


\section{Al-Dadhi : Jurnal Hukum Keluarga Islam}

adanya kasus pernikahan hamil karena zina yang terjadi secara repetitif tanpa adanya upaya penanggulangan yang maksimal. Repetisi kasus pernikahan wanita hamil karena zina bahkan diiringi dengan adanya sikap yang permisif secara kultural. Sikap ini direfleksikan dengan resepsi pernikahan semacam ini, sebagian besar dipestakan sebagai pernikahan normal, sehingga kesan risih, malu atau aib menjadi sebuah pemakluman. Distorsi pemahaman terkait dengan pernikahan wanita hami karena zina menjadi fakta sosial yang merepresentasikan persepsi masyarakat yang kontradiktif terhadap upaya penanggulangan persoalan pernikahan wanita hami karena zina.

Pada aspek yang lain, yakni terkait perbuatan zina yang menyebabkan adanya peristiwa pernikahan hamil, dalam perspektif fikih tidak ada perselisihan tentang sanksi hukum yang diterapkan terhadap pelaku zina. Dengan demikian, di dalam hukum Islam tidak dapat dipisahkan antara peristiwa pernikahan wanita hamil karena zina itu sendiri dengan perbuatan hukum yang menyebabkannya. Pernikahan yang dilakukan tidak berarti menghilangkan sanksi hukum bagi pelaku zina.

Fenomena pernikahan wanita hamil karena zina menjadi indikator rendahnya efektifitas fungsi hukum dalam konteks upaya penanggulangan persoalan ini. Pandangan kelaziman dan pemakluman dalam hal ini kemudian dapat menjadi salah satu satu faktor pemicu kasus-kasus pernikahan wanita hamil karena zina terjadi. Oleh karena itu, pendekatan sosio kultural seharusnya mengambil peran penting dalam hal ini. Ketentuan formal negara yang hanya terkait persoalan keperdataan dapat mereduksi aspek jarimah yang tidak diakomidir di dalam tata hukum nasional. Namun realitas sosio kultural masyarakat Metro Utara secara emperik menunjukkan kurangnya perhatian dan bahkan pemakluman dalam kasus peristiwa pernikahan wanita hamil karena zina yang terjadi.

Hukum dalam kaitannya dengan antropologi dipandang sebagai salah satu aspek dari kebudayaan yang merupakan bagian dari tema dalam sosio kultural antropologi. ${ }^{2}$ Oleh karena itu, pendekatan sosio kultural dapat menjadi alternasi dalam menyikapi fenomena peristiwa pernikahan wanita hamil karena zina dan memahami kontruksi hukum yang tepat.

Persepsi hukum formal yang kurang menyentuh adanya unsur penyimpangan norma dalam permasalahan peristiwa pernikahan wanita hamil karena zina sebagai bagian dari permasalahan sosial memberikan implikasi lemahnya keberfungsian hukum dalam hal pengendalian sosial. Demikian pula dengan persepsi sosio kultural pada masyarakat yang semestinya dapat mengambil peran dalam hal pencegahan maupun penanggulangan kasus pernikahan wanita hamil karena zina yang terjadi. Kekuatan sosial kultural yang telah hidup jauh sebelum formalisasi hukum dengan nilai-nilai norma susila, norma agama, dan berbagai pola interkasi masyarakatnya merupakan aspek penting yang mampu mengambil peran dalam pengendalian sosial termasuk dalam bidang hukum pernikahan. Namun, realitanya justru merepesentasikan pergeseran nilai terhadap persoalan ini.

Sikap apatis atau rendahnya kepedulian sosial, individualisme, ketidakenakan, dan permisifnya masyarakat berimplikasi terhadap minimnya

\footnotetext{
${ }^{2}$ T.O. Ihromi, Antropologi Hukum, (Jakarta: Yayasan Obor Indonesia, 1984), h. 4.
} 


\section{Al-Dadhi : Jurnal Hukum Keluarga Islam}

upaya penanggulangan persoalan peristiwa pernikahan wanita hamil karena zina. Hal ini juga diindikasikan dengan persepsi pemahamahan dan kesadaran masyarakat terhadap hukum pernikahan wanita hamil karena zina yang tidak menunjukkan bahwa persoalan peristiwa pernikahan ini sebagai permasalahan sosial yang mengkhawatirkan. Hal ini menjadi kajian yang perlu untuk dilakukan karena permasalahan peristiwa pernikahan wanita hamil karena zina berimplikasi hukum serta soiologis yang ikut mempengaruhi struktur sosial dalam konteks keterwujudan ketertiban hukum.

\section{ANALIASIS TERHADAP KEDUDUKAN KAWIN HAMIL DALAM TATA HUKUM FORMAL DI INDONESIA}

Terkait dengan ketentuan kawin hamil secara implisit di dalam tata hukum di Indonesia hanya terdapat di dalam KHI yakni pada Bab VIII pasal 53. Dengan demikiahn dapat dikatakan bahwa konsideran KHI ini merupakan suatu ketentuan tentang persoalan kawin hamil yang bersifat legal formal yang bahkan di dalam Undang-undang Nomor 1 tahun 1974 tentang perkawinan, persoalan ini tidak diatur.

Keberadaan ketentuan kawin hamil di dalam KHI ini merupakan bagian dari representasi dari tujuan KHI secara umum. Pemahaman tentang kawin hamil dalam perspektif fikih memang memiliki beragam pandangan. Oleh karena itu konsideran KHI nampak jelas merepresentasikan tujuan unifikasi hukum. Dengan demikian, hukum menikahkan wanita hamil yang diakibatkan perzinahan oleh laki-laki dan wanita yang belum atau tidak memiliki status ikatan hukum, secara normatif telah memiliki kepastian hukum melalui pasal 53 KHI. Dalam hal ini negara menentukan bahwa sah menikahkan pelaku kawin hamil. Sah dalam hal ini berarti sahnya sebagiamana perkawinan pada umumnya. Tidak ada larangan untuk berkumpul (berhubungan suami istri) dan tidak ada pernikahan ulang. Namun ketentuan ini hanya ditujukan kepada lakilaki yang menghamili bukan ditujukan kepada orang yang bukan menghamili. Dengan adanya ketentuan ini maka pihak-pihak yang berwenang dalam hal tidak ada alasan untuk tidak menikahkan pelaku kawin hamil.

Terkait dengan ketentuan KHI sebagai produk hukum yang terformalisasi dalam tata hukum nasional maka untuk memahami persoalan kawin hamil dalam perspektif normatif harus dielaborasi dengan ketentuan perudangan lain yang berkaitan. Selain itu, melihat persoalan kawin hamil ini tidak dipahami secara parsial, namun perlu dilihat secara utuh. Sebagai suatu persoalan hukum maka ia tidak bisa dilepaskan dari hal-hal yang mengiringinya, baik persitiwa yang mendahuluinya maupun konsekuensi yang disebabkannya. Dan kesemua itu secara normatif dapat ditinjau dari perspektif hukum formal di Indonesia.

Terkait dengan tindakan perzinahan sebagai persoalan yang tidak dapat dilepaskan dari kawin hamil, dalam hukum formal di Indonesia diatur melalui KUHP. Konteks perzinahan pada kawin hamil di dalam penelitian ini, secara normatif akan sulit ditarik sebagai tindak pidana. Hal ini terkait dengan klasifikasi tindak pidana zina dalam KUHP yang mensyaratkan adanya aduan dari pihak yang merasa dirugikan, atau jika dikaitkan dengan usia pelaku.

Berdasarkan hal-hal tersebut di mana pelaku (baik laki-laki maupun wanita) umumnya masih dalam kategori di bawah umur sehingga dinilai 


\section{Al-Dadhi : Jurnal Hukum Keluarga Islam}

belum cakap hukum atau rasionalitas bahwa delik aduan yang disyaratkan di dalam KUHP dinilai sebagai tindakan yang justru merugikan ke dua belah pihak (laki-laki maupun wanita). Oleh karenanya, sangat jarang atau bahkan tidak ada kasus seperti ini sampai ke dalam ranah hukum. ${ }^{3}$ Dan tindakan yang dinilai tepat dan memiliki landasan hukum yang jelas adalah dengan menikahkan pelaku.

Tindakan yang diambil demikian ini tentu secara normatif dan legal formal tidak ada yang keliru, para pemilik kewenangan (steak holder) telah sesuai dengan ketentuan konstitusional yang ada. Dengan demikian, nampak bahwa dalam peristiwa hukum kawin hamil ini tidak terdapat instrumen legal punishment karena tidak diatur dalam peraturan perundangan.

Berbeda dengan kedudukan kawin hamil dalam konstruksi hukum nasional, antara aspek keperdataan dan pidana yang tidak terintegralistik menunjukkan bahwa dalam persoalan kawin hamil dalam konteks sebuah "permasalahan hukum" tidak merepresentasikan peristiwa yang mengganggu eksistensi keberadaban. Indikasi dari hal ini diperkuat dengan ketiadaan landasan legal formal yang menjadi landasan hukum tindakan penanggulangan atau sanksi di dalamnya.

Kawin hamil sebagai sebuah masalah sosial yang dalam perspektif hukum Islam memiliki konsekuensi hukum berupa sanksi yang melekat sekalipun tidak menghilangkan hak menikah terhadap pelaku. Oleh karenanya, pemahaman hukum yang harus dibangun dalam melihat persoalan kawin hamil sebenarnya bukan soal sah atau tidak sah perkawinan yang dilangsungkan namun memberikan posisi hukum terkait aspek pelanggaran yang terjadi pada kasus kawin hamil ini.

Pelanggaran hukum yang ada pada kasus kawin hamil antara lain adalah dalam konteks hukum perlindungan anak, jika dalam kasus kawin hamil ini melibatkan pelaku di bawah umur. Keterjerumusan subjek hukum yang masih dinilai tidak atau belum dianggap cakap maka yang patut dipertanyakan adalah tanggungjawab perwalian. Adanya unsur kelalaian saja dalam beberapa kasus dapat menjadikan pemegang perwalian dipersalahkan dihadapan hukum, terlebih jika terdapat unsur kesengajaan atau pembiaran yang menyebabkan orang yang di bawah perwaliannya mengalami kerugian dalam perspektif hukum. Oleh karena itu, adanya kasus kawin hamil yang disebabkan karena adanya perbuatan persetubuhan yang tidak dalam ikatan hukum yang sah, yang dengan sengaja melanggar norma susila maupun agama dan tidak sedikit hal tersebut dikarenakan kelalaian atau bahkan pembiaran oleh orang tua, maka dalam hal ini orang tua mengabaikan nilai-nilai perlindungan terhadap anak. Sebagaimana dipahami bahwa akibat yang ditimbulkan dari perkawinan hamil bagi pelaku akan merenggut masa depan anak. Selain itu, dari aspek psikologis maupun ekonomis, pelaku kawin hamil terutama bagi yang di masih bawah umur akan sangat rentan untuk mengalami berbagai persoalan yang dapat menghambat dalam mewujudkan rumah tangga yang diharapkan.

Kasus kawin hamil ini pun dalam tinjauan perwujudan tujuan hukum, merefleksikan perbuatan yang kontradiktif terhadap pembentukan hukum itu sendiri. Dengan kata lain, dalam perspektif konstitusional ketika bidang

3 YR/wcr.22/lh.kr., Wawancara, Karangrejo, 06 Oktober 2016.

4 


\section{Al-Dadhi : Jurnal Hukum Keluarga Islam}

perkawinan secara legal formal telah diperundang-undangkan namun terdapat praktek yang tidak sesuai atau bahkan bertentangan dengan perundangundangan yang ada berarati hal tersebut mendegradasi tujuan dari dibuatnya ketentuan perundangan tersebut. Oleh karena itu kasus kawin hamil ini bukan saja merupakan masalah sosial namun ia menjadi masalah hukum yang jika tidak menjadi perhatian serius akan menimbulkan ketidakteraturan pada masyarakat yang memunculkan masalah-masalah baru yang lebih besar.

\section{POSITIFIKASI DAN EFEKTIVITAS HUKUM DALAM KETENTUAN KAWIN HAMIL SEBAGAI INSTRUMEN PENGENDALI SOSIAL.}

Hukum Islam sebagai bagian dari hukum positif di Indonesia memiliki kedudukan penting dalam kehidupan masyarakatnya. Namun demikian dalam penerapannya terdapat beberapa persoalan yang kompleks. Hukum Islam sebagai suatu ketentuan yang bersifat dogmatis menuntut penganutnya untuk melaksanakan ketentuan tersebut, namun realitas bahwa Indonesia bukan sebagai negara Islam maka bagi masyarakat muslim di Indonesia dalam pelaksanaan hukum Islam tidak dapat diterapkan secara utuh. Selain itu, sikap masyarakat sendiri juga menunjukkan keterikatannya kepada hukum adat yang masih dipegangi dalam beberapa aspek kehidupan menunjukan perkembangan dan pembangunan hukum nasional tidak dapat daat dilepaskan dari kenyataan dan kesadara hukum yang ada di masyarakat.

Terlepas dari kompleksitas tersebut, perkembangan hukum Islam di Indonesia menunjukkan progres yang cukup signifikan. Berbagai bidang hukum Islam secara legal telah dilegalisasi dalam bentuk perundangan. Hal ini membuktikan bahwa urgensi dan eksistensi hukum Islam dalam pembinaan hukum nasional merupakan keniscayaan dan memiliki peran penting dalam penegmbangan hukum nasional.

Pembahasan terkait hukum Islam di Indonesia maka akan menunjukkan dua sisi. Hukum Islam dalam hal ini akan menampakkan diri sebagai hukum yang bersifat universal dengan daya jangkau untuk semua tempat dan segala zaman, tetapi di lain sisi ia akan menunjukkan hukum yang memiliki sifat fleksibel dan kekhasan ekspresi praktek keberagamaan di Indonesia.

Rangkaian perkembangan hukum Islam di Indonesia sebagaimana proses Islamisasi yang tidak pernah mencapai titik final. Oleh karenanya bentuk ideal terus dikembangkan dalam tata hukum nasional. Progres positif ini ditandai dengan berbagai upaya penyempurnaan materi hukum Islam yang diformalisasi dalam tata hukum nasional.

Konsepsi hukum Islam di Indonesia dalam aspek penerapannya banyak memunculkan penyesuaian-penyusuaian pada kondisi dan budaya di Indonesia sehingga terkadang menampakkan disparitas hukum. Hal ini sebenarnya sesuatu yang lazim dalam perspektif fikih dengan kerangka ikhtilaf-nya. Namun kemudian, dalam perkembangan masyarakat hukum saat ini kondisi tersebut menjadi persoalan yang merefleksikan ketidakpastian hukum.

Persoalan tersebut sebagaimana dalam setting yang melatarbelakangi penyusunan Kompilasi Hukum Islam (KHI). Sebelum KHI ini disahkan penemu hukum (hakim) di lingkungan Peradilan Agama memiliki kebebasan menemukan hukum dengan menggunakan pedoman yang berbeda antara satu 


\section{Al-Dadhi : Jurnal Hukum Keluarga Islam}

hakim dengan hakim yang lain. Implikasi dari hal ini kemudian menghasilkan keputusan pengadilan yang berbeda dalam satu persoalan yang sama. Oleh karena itu perlu adanya unifikasi rujukan atau pedoman material hukum di lingkungan Peradilan Agama. Melalui keberadaan KHI ini maka diharapkan kepastian hukum dengan penggunaan pedoman yang sama maka disparitas keputusan pengadilan dapat diminimalisir sehingga terwujud kepastian hukum di masyarakat.

KHI merupakan produk hukum nasional yang memiliki urgensi dan kedudukan strategis dalam perkembangan Hukum Islam dengan corak keIndonesia-annya. Sekalipun KHI hanya mencakup persoalan hukum di bidang keperdataan yang tidak jauh berbeda dengan formula fikih normatif umumnya, namun secara substantif materi hukum Islam di dalam KHI dinilai cukup lengkap dan dapat melengkapi peraturan perundangan yang telah ada. Selain itu, KHI menjadi representasi produk hukum yang menunjukkan adaptabilitas hukum Islam di Indoensia. Hal ini nampak pada beberapa ketentuannya seperti pada pasal 85 tentang harta bersama dalam perkawinan, pasal 183 tentang perdamaian dalam pembagian waris, pasal 185 tentang ahli waris pengganti, pasal 189 tentang kewarisan kolektif. Ketentuan-ketentuan pada konsideran tersebut merupakan terobosan atau modifikasi hukum diorientasikan kepada kondisi dan kebutuhan hukum yang ada pada masyarakat muslim di Indonesia.

Semangat positivikasi hukum Islam dan ketentuan lainnya dalam tata hukum nasional merupakan sebuah keniscayaan dalam perkembangan hukum di Indonesia. Asas legalitas hukum yang menjadi salah satu prinsip hukum lex scripta menekankan pada pendekatan hukum tertulis. Hal tersebut sebenarnya bukan merupakan suatu persoalan bahkan memberikan nilai-nilai kepastian hukum yang jelas dan merupakan refleksi dari dinamika hukum modern.

Semangat positivisme hukum di Indonesia juga merambah kepada hukum Islam di Indonesia. Hal ini sebagaimana tercermin dari berbagai bidang hukum Islam seperti perkawinan, wakaf, ekstensifikasi kewenangan absolut Peradilan Agama, serta berbagai perda yang mengakomodir hukum Islam masuk dalam ranah legeslasi. Namun demikian, di lain sisi kecenderungan yang mengarah kepada hukum yang terikat pada aspek-aspek tekstual dengan hanya berpegang kepada aturan-aturan tertulis yang selanjutnya akan membawa kepada kekakuan pradigma hukum masyarakat.

Hal tersebut nampak dari berbagai peristiwa yang menggambarkan nilainilai hukum yang banyak dipahami secara pragmatis. Orang akan mudah membawa persoalan-persoalan yang dianggapnya dapat dibawa ke meja hijau tanpa mempertimbangkan aspek-aspek lain yang dapat membawa ekses yang kontradiktif terhadap tujuan hukum itu sendiri akibat proses peradilan formal tersebut. Persitiwa-persitiwa hukum tersebut misalnya beberapa kasus bagaimana seorang anak menggugat orang tua kandungnya karena merasa lebih berhak terhadap rumah yang ditempati orangtuanya tersebut. ${ }^{4}$ Kasus lainnya, bagaimana pihak perusahaan besar memidanakan nenek yang mencuri

4 Liputan6.com, Ibu 90 Tahun Digugat Rp 1 Milyar oleh Anak Kandungnya, 23 September 2014.

6 


\section{Al-Dadhi : Jurnal Hukum Keluarga Islam}

tiga buah kakao, ${ }^{5}$ atau seorang nenek yang harus dipidanakan karena menebang sebatang pohon di pekarangan rumahnya karena dinilai melakukan illegal loging di dalam lahan perhutani. ${ }^{6}$

Terlepas dari adanya unsur-unsur perbuatan melawan hukum yang terjadi pada persitiwa-peristiwa tersebut, dalam perspektif sosiologi hukum hal itu tidak menunjukkan refleksi tujuan hukum tentang keadilan. Hal ini diperparah dengan kenyataan di bidang hukum yang menunjukkan fakta yang kontradiktif terhadap bagaimana sanksi hukum terhadap koruptor yang merugikan negara ratusan hingga milyaran rupiah dengan sanksi hukum yang tidak sebanding dengan jumlah kerugian negara, atau penanganan hukum terhadap pengusaha besar yang terus merusak alam baik dengan usaha penambangan atau perambahan hutan yang membuat masyarakat semakin skeptis terhadap penegakkan hukum di Indonesia. Peristiwa-persitiwa hukum tersebut selanjutanya dapat membentuk persepsi terhadap ketimpangan penegakkan hukum yang demikian ini, jika dikomparasikan dengan begitu tajamnya penegakkan hukum terhadap masyarakat kecil.

Arah hukum yang demikian ini kemudian menarik kepada upaya pengelaborasian kedudukan hukum kawin hamil di dalam hukum formal di Indonesia. Hal ini berdasarkan realitas persoalan bahwa terdapat paradigma sosial yang memandang bahwa kawin hamil bukan menjadi bagian dari masalah sosial yang urgen. Persoalan kawin hamil ini akan semakin nampak diabaikan jika sudah dikomparasikan dengan apa yang disebut dengan extra ordinary crime, seperti korupsi, terorisme, dan narkoba. Ketiga kategori tersebut memang tidak dapat dipungkiri memiliki dampak yang besar bagi kehidupan bermasyarakat, dan demikian pula pada tindak pidana lainnya dalam KUHP yang di dalamnya ketentuan-ketentuannya merepresentasikan perlindungan terhadap keberadaban manusia.

Keterikatan penerapan hukum pada asas legalitas secara emperis ikut membatasi peran hukum terhadap permasalahan-permasalahan yang berkembang di masyarakat. Selain itu, dualisme perspektif terhadap mendudukkan kawin hamil dalam tata hukum nasional, di mana aspek keperdataan yang terkandung di dalamnya menggunakan perspektif "fikih" sementara di aspek yang lain terkait dengan pelanggarannya menggunakan perspektif hukum pidana. Hal ini ikut mempengaruhi lemahnya peran hukum dalam konteks penanggulangan fenomena kasus kawin hamil. Instrumen hukum dalam hal ini akan sulit masuk ke dalam ranah privat karena aspek normatif memberikan kepastian yang tegas tidak ada persoalan menikahkan para pelaku kawin hamil tanpa adanya unsur terkait persoalan permasalalahan hukum dan masalah sosial di dalamnya.

Persoalan ketiadaan aturan normatif yang dapat manarik kepada aspek pelanggaran dalam konteks zina tidak berarti mendudukkan kasus kawin ini sebagai sebuah persitiwa yang terbebas dari unsur-unsur pelanggaran yang diabaikan begitu saja sebagaimana paradigma dan praktek yang terjadi pada masyarakat Kecamatan Metro Utara. Kasus kawin hamil dengan perbuatan

5 Antaranews.com, Tiga Butir Kakao Membawa Minah ke Pengadilan, 20 November 2009.

6 Liputan6.com, Nenek Asyani Terdakwa Pencuri Kayu Divonis 1 Tahun Penjara, 23 April 2015. 


\section{Al-Dadhi : Jurnal Hukum Keluarga Islam}

pendahuluan yang melekat padanya berupa zina yang terjadi secara masif ikut membangun persepsi yang melazimkan hal tersebut. Hal ini selanjutnya menjadikan persoalan kawin hamil tidak menjadi isu penting yang patut menjadi persoalan serius dalam kehidupan bermasyarakat.

Oleh karena itu, untuk menyikapi hal ini, tidak dapat hanya berorentasi kepada aspek normatif dengan asas legalitasnya. Asas legalitas sebagai landasan kepastian hukum tidak seharusanya mereduksi fungsi hukum itu sendiri. Keadaan yang demikian ini menjadi tantangan bagi masyarakat hukum untuk menyikapi kondisi dan persoalan yang ada pada masyarakat tersebut.

Pendekatan hukum terhadap peristiwa kawin hamil menggunakan kearifan lokal sangat mungkin dilaksanakan, melalui kesepahaman bersama tentang suatu persoalan hukum atau konsensus masyarakat yang merepresentasikan elemen sosial adalah hal yang tidak bertentangan secara konstitusional. Pemahaman ini didasarkan pada UU Kekuasaan Kehakiman nyatanyata telah memberikan kewenangan, bahwa Peradilan negara menerapkan dan menegakkan hukum dan keadilan berdasarkan Pancasila" Pada ketentuan berikutnya ditegaskan, bahwa hakim wajib menggali, mengikuti, dan memahami nilai-nilai hukum dan rasa keadilan yang hidup dalam masyarakat. ${ }^{7}$

Dengan demikian, ketika peristiwa kawin hamil dengan pihak-pihak yang terlibat di dalamnya (pelaku) dinilai mengganggu tatanan ketertiban dan kenyamanan bersama maka masyarakat berpeluang dan berhak memberikan kebijakan untuk memberikan punishment sebagai wujud perlindungan terhadap ketertiban masyarakat. Dan sebenarnya kearifan dan kebijakankebijaan semacam ini secara emperik juga telah dilakukan oleh masyarakat misalnya, kebijakan denda terhadap pembatalan nikah.

Dinamika sosial yang terus berkembang menuntut hukum untuk dapat mengiringi dan memberikan jawaban-jawaban terhadap permasalahan yang ada. Di sinilah progresifitas hukum memiliki peran penting, ketika hukum yang dikonseptualisasikan dengan teks yang terbatas, aktualisasi dari fungsi hukum melalui penemuan dan penggalian hukum tanpa dibatasi dengan kekakuan teks hukum. Dengan demikian ketika kawin hamil dengan ketentuan yang ada belum merepresentasikan perlindungan terhadap ketertiban, maka masyarakat dapat menggunakan perangkat-perangkat lain yang memungkinkan untuk menyikapi kekosongan aspek ini. Bahkan dalam sejarah penerapan hukum Islam yang secara tekstual telah ada pun masih dimungkinkan adanya penemuan hukum di luar teks yang ada sekaipun sebagai upaya untuk lebih memungkinan kemashlahatan masyarakat itu sendiri.

Ketiadaan alas hukum yang kemudian menjadi alasan untuk mengabaikan kawin hamil sebagai permasalahan sosial merupakan persoalan yang harus di-review secara kritis. Terkait dengan penanganan kasus zina, di mana dimensi sosiologis dalam beberapa kasus dapat lebih dikedepankan daripada pendekatan hukum formal. Hal ini menunjukkan bagaimana pertimbangan masyarakat menilai tindakan yang dipilih merupakan terobosan

7 Pasal 3 ayat (2) jo. Pasal 28 ayat (1) Undang-Undang Nomor 4 Tahun 2004 tentang Kekuasaan Kehakiman. 


\section{Al-Dadhi : Jurnal Hukum Keluarga Islam}

hukum yang tepat dengan berorientasi kepada tujuan hukum yang ada. Tindakan ini seharusnya juga dapat digunakan dalam menyikapi kasus kawin hamil yang secara tekstual tindakan yang bersifat kuratif tidak diatur. Namun pada kenyataannya hal tersebut tidak dilakukan terhadap kasus kawin hamil.

\section{IMPLIKASI PERSITIWA PERKAWINAN WANITA HAMIL KARENA ZINA DALAM PERSPEKTIF SOSIO KULTURAL MASYARAKAT KECAMATAN METRO UTARA}

Perkawinan wanita hamil karena zina merupakan perkawinan yang didahului dengan suatu perbuatan yang mengandung unsur pelanggaran norma, baik itu norma agama maupun norma susila, bahkan dalam kondisi tertentu dapat pula dinilai sebagai bentuk pelanggaran hukum. Perbuatan pendahuluan ini merupakan bentuk persetubuhan yang dilakukan di luar ikatan yang sah, yang dalam terminologi agama disebut zina. Perbuatan zina sebagai salah satu bentuk pelanggaran dalam ketentuan hukum Islam memiliki konsekuensi hukum berupa sanksi yang cukup berat didera hingga dirajam. Sanksi yang demikian ini tentu secara sosiologis berimplikasi kepada persepektif masyarakat terhadap pelaku. Kawin hamil dalam hal ini tidak hanya dinilai sebagai pelanggaran norma sosial namun juga sebagai pelanggaran norma hukum karena memiliki unsur mengganggu ketertiban umum.Bahkan terkait dengan dampak hukum perkawinan wanita hamil karena zina, sebagaimana kaidah fiqhiyah :

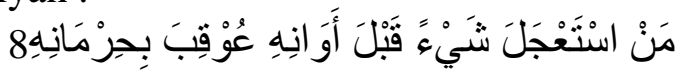

"Barangsiapa yang mempercepat sesuatu sebelum waktunya, maka menanggung akibat tidak mendapatkan sesuatu tersebut"

Berdasarkan kaidah tersebut maka konsekuensi menurut Hukum Islam dari perbuatan zina yang dalam hal ini merupakan perbuatan pendahuluan yang menyebabkan adanya perkawinan hamil tersebut adalah hilangnya hakhak yang seharusnya diperoleh bagi pelakunya, yakni hilangnya hak kenasaban anak yang dikandung kepada bapak biologisnya. Peristiwa kawin hamil di Kecamatan Metro Utara secara kuantitas tidak ditemukan pada dokumen resmi dari pihak manapun baik di KUA maupun di kelurahan atau kecamatan. Namun tidak dapat dipungkiri bahwa kasus kawin hamil adalah suatu hal yang banyak terjadi. ${ }^{9}$

Ketentuan hukum formal secara jelas dan tegas memberikan ketentuan bahwa perkawinan hamil adalah sah dan tidak diperlukan lagi nikah ulang setelah bayi yang dikandung telah lahir, sebagaimana ketentuan pada pasal 53 KHI ayat (3). Oleh karenanya, bagi petugas KUA secara prosedural tidak ada standar pemeriksaan terkait hal ini. Sekalipun langsung atau tidak langsung indikasi-indikasi bahwa kasus kawin hamil ditemukan saat pendaftaran di KUA. Indikasi tersebut di antaranya adanya unsur kesan mendesak atau mendadak dalam proses pendaftaran pernikahan. Informasi adanya kasus kawin hamil juga didapat dari pengakuan dari orang yang mendaftarkan perkawinan yang umumnya tokoh agama atau "Pak Kaum" atau pamong (

8 Muhammad Bikr Ismail, Qawaid Fiqhiyah Bainal Ashliyah wa At Taujih, (t.t.p: Dar al Manar, 1997), h. 124.

9 YR/wcr.22/lh.kr, Wawancara, Karangrejo, 06 Oktober 2016. 


\section{Al-Dadhi : Jurnal Hukum Keluarga Islam}

Ketua RT atau RW) yang diminta untuk membantu mengurus hal-hal yang diperlukan untuk proses pernikahan. ${ }^{10}$

Permasalahan perkawinan yang banyak ditangani di KUA Kecamatan Metro Utara adalah persoalan pernikahan di bawah umur, sedangkan untuk persoalan kawin hamil, pihak KUA tidak menjadikannya sebagai persoalan yang dapat menghalangi seseorang untuk menikah. Oleh karena itu, dalam prosedur pemeriksaan terhadap calon pengantin tidak diperiksa terkait persoalan ada tidaknya kawin hamil. Persoalan kemudian dinikahkan ulang atau tidak juga menjadi kemantapan masing-masing, namun dalam prakteknya banyak dari masyarakat melaksankan nikah ulang tersebut. ${ }^{11}$

Dengan demikian, penanganan terahadap kasus kawin hamil di KUA Kecamatan Metro Utara, secara formal lebih diarahkan kepada status hukum (ada tidaknya ikatan perkawinan sebelumnya) calon pengantin. Hal ini disebabkan karena sekalipun diketahui adanya kehamilan sebelum terjadi pernikahan pada calon pengantin maka sesuai dengan hukum formal yang ada, maka tidak ada persoalan dalam menikahkannya sebagaimana pada ketentuan KHI Pasal 53 ayat (3).

\section{A. PENUTUP}

Pernikahan wanita hamil karena zina merupakan persoalan hukum sekaligus persoalan sosial. Berdasarkan penelitian tentang realitas Pernikahan wanita hamil karena zina yang terjadi di Kecamatan Metro Utara maka dapat disimpulkan hal-hal sebagai berikut :

Persepsi masyarakat Metro Utara terhadap ketentuan hukum terkait pernikahan wanita hamil karena zina banyak dipengaruhi oleh fungsi pranata sosial melalui tokoh agama dan tokoh masyarakat, hal ini berimplikasi terhadap efektifitas dan pemahaman masyarakat terhadap hukum formal terkait persoalan pernikahan hamil.

Pernikahan wanita hamil karena zina yang terjadi di Kecamatan Metro Utara sebagai suatu realitas sosial yang dinilai biasa kemudian mengkonstruksikan paradigma sosiologis masyarakat Kecamatan Metro Utara yang secara emperik menggambarkan kepermisifan masyarakat terhadap kasus wanita hamil karena zina.

Upaya penanggulangan terhadap persoalan pernikahan wanita hamil karena zina telah dilakukan oleh berbagai pihak di Metro Utara. Upaya tersebut meliputi upaya preventif, kuratif, maupun represif. Namun upayaupaya yang ada masih bersifat pragmatis dan insidentil.

Kepastian hukum yang ditransformasikan dalam aturan perundanganundangan tidak ditujukan sebagai pengekang fungsi hukum yang terikat pada aspek tekstual. Oleh karena itu, bagi pihak-pihak terkait, steakholder, pemangku kepentingan untuk lebih mengedepankan kondisi dan kebutuhan

10 Kmd/wcr.11/phl.mu., Wawancara, Purwosari, 09 September 2016.

11 Kmd/wcr.11/phl.mu., Wawancara, Purwosari, 09 September 2016. 


\section{Al-Dadhi : Jurnal Hukum Keluarga Islam}

masyarakat dengan menggunakan alternasi sumber hukum yang digali dari kearifan lokal, konsensus yang berakar dari tradisi yang dapat digunakan sebagai pendekatan hukum untuk menanggulangi peristiwa pernikahan wanita hamil karena zina yang terjadi.

Prediket Kota Metro sebagai kota pendidikan dengan segala peraturan daerah seperti pemberlakuan jam belajar, serta jam malam harus benar-benar dijalankan hingga ke RT-RT. Kebijakan-kebijakan yang positif ini akan lebih efektif jika dapat menggandeng elemen-elemen masyarakat yang ada seperti RISMA, majleis ta'lim, Karang Taruna, atau FKPM bahkan Linmas sebagai mitra pemerintah untuk mengontrol kebijakan tersebut.

Sikap kegotongroyongan masyarakat Kecamatan Metro Utara merupakan modal penting dalam rangka penanggulangan pernikahan wanita hamil karena zina yang terus muncul. Setiap elemen yang ada di masyarakat sepatutnya menyadari bahwa persoaln ini merupakan permasalahan sosial yang harus mendapatkan perhatian serius. Kesadaran ini harus dimanifestasikan pada sebuah sistem yang tidak hanya bersifat insidentil Pendeknya untuk menyikapi dan menanggulangi terjadinya kasus wanita hamil karena zina di Kecamatan Metro Utara diperlukan adanya goodwill dari semua pihak.

\section{DAFTAR PUSTAKA}

T.O. Ihromi, Antropologi Hukum, (Jakarta: Yayasan Obor Indonesia, 1984),

Liputan6.com, Ibu 90 Tahun Digugat Rp 1 Milyar oleh Anak Kandungnya, 23 September 2014.

Antaranews.com, Tiga Butir Kakao Membawa Minah ke Pengadilan, 20 November 2009.

Liputan6.com, Nenek Asyani Terdakwa Pencuri Kayu Divonis 1 Tahun Penjara, 23 April 2015.

Muhammad Bikr Ismail, Qawaid Fighiyah Bainal Ashliyah wa At Taujih, (t.t.p: Dar al Manar, 1997) 